\title{
Impact of Reuse Water on Golf Course Soil and Turfgrass Parameters Monitored Over a 4.5-Year Period
}

\author{
Anne M. Lockett ${ }^{1}$ \\ Department of Water Resource Management, University of Nevada Las \\ Vegas, Las Vegas, NV 89154
}

Dale A. Devitt ${ }^{2,4}$

School of Life Sciences, University of Nevada Las Vegas, 4505 Maryland Parkway, Las Vegas, NV 89154

Robert L. Morris
University of Nevada Cooperative Extension, Las Vegas, NV 89123

Additional index words. irrigation, salinity, bermudagrass, ryegrass

\begin{abstract}
Population growth and water limitations in the southwestern United States have led to golf courses in many communities to be encouraged or mandated to transition to reuse water for irrigation purposes. A monitoring program was conducted on nine golf courses in the Las Vegas valley, $\mathrm{NV}$, for 4.5 years to assess the impact of reuse water on soil-turfgrass systems \{bermudagrass [Cynodon dactylon (L.) Pers.], perennial ryegrass (Lolium perenne L.), bentgrass (Agrostis palustris Huds.)\}. The nine courses selected included three long-term reuse courses, three fresh water courses, and three courses expected to transition to reuse water during the monitoring period. Near-surface soil salinity varied from 1.5 to $40.0 \mathrm{dS} \cdot \mathrm{m}^{-1}$ during the study period with the highest peaks occurring during summer months and on long-term reuse irrigated fairways. Although soil salinity at several depths on fairways and greens increased after transition to reuse water, this did not lead to a systematic decline in leaf xylem water potential $\left(\Psi_{L)}\right.$ or color. When the data were grouped as fresh, transition, or reuse irrigated, soil salinity on reuse courses were statistically higher $(P<0.05)$ than fresh and transitional courses, yet plant response on reuse courses was not statistically different $(P>0.05)$ than that observed on fresh courses. The fact that summertime plant parameter values often declined under lower salinity levels and the electrical conductivity of the irrigation water was rejected as a significant variable in all backward regression analysis to describe plant response indicated that management differed significantly from course to course. We conclude that proper irrigation management, based on a multitiered feedback system (soil-plantatmospheric monitoring), should be able to maintain favorable salt balances and plant response as long as irrigation volumes are not restricted to where deficit irrigation occurs.
\end{abstract}

Explosive population growth in southern Nevada has placed increasing demands on available water resources. In $2007,80 \%$ of the state population occurred in southern Nevada, which had a population approaching 2.0 million people (Southern Nevada Health District). This, coupled with a severe drought, has caused water managers to investigate all possible water resources, including

Received for publication 30 Apr. 2008. Accepted for publication 18 Aug. 2008

${ }^{1}$ Graduate Student.

${ }^{2}$ Professor, Soil and Water.

${ }^{3}$ Associate Professor.

We thank the Southern Nevada Water Authority for their financial support for this research, Gary Grinnell of Las Vegas Valley Water District, and Joseph Leising of SNWA. We also thank Polly Conrad, Lena Wright, Brian Bird, and all of the workers in the laboratory of Dr. Dale Devitt at UNLV for their field and laboratory assistance.

${ }^{4}$ To whom reprint requests should be addressed; e-maildev50@clark.nscee.edu

systems. However, use of poor-quality water for irrigation purposes requires state-of-theart, science-based management practices (Carrow and Duncan, 1998; U.S. Golf Association, 1994).

Successful development of a program for reuse water use in southern Nevada has evolved closely with the golf course industries and the general public's acceptance of reuse water. Southern Nevada is home to 53 golf courses, many of them high-end, premiere courses (Gary Grinnell, LVVWD, personal communication). Las Vegas has become one of the United States' fastest growing golf destinations with golf representing a significant contribution to the Las Vegas tourism-driven economy (Borden and Fletcher, 2003).

Use of reuse water does have limitations as a result of its water quality. Superintendents in southern Nevada have expressed concerns over the use of reuse water because of certain "hidden costs" associated with its use. These "hidden costs" include foliar damage to ornamental plants, decline in water quality and aesthetic value of irrigation ponds and water features, "wear and tear" on equipment, the long-term salt buildup in soil profiles, and increased levels of turfgrass stress (Devitt et al., 2004). As such, we initiated a long-term monitoring program to address these concerns, many of which have already been reported on (Devitt et al., 2004, 2005, 2007). In this article, we report on the salt buildup in soil profiles and plant response over a 4.5-year period associated with the irrigation of golf courses with different sources of water. In particular, we monitored golf courses during the period of study that used reuse water (greater than 20 years), hereafter referred to as reuse courses; fresh water, hereafter referred to as fresh courses; and/or transitioned to reuse water, hereafter referred to as transition courses.

\section{Material and Methods}

waters of lower quality, to alleviate this supply-demand dilemma in southern Nevada.

Las Vegas operates on a "Return Flow Credit" program for reuse water returned to Lake Mead after tertiary treatment. The city of Henderson, the city of Las Vegas, and the Clark County Sanitation District all release a portion of their treated wastewater for irrigation reuse, whereas the remainder is returned to the Colorado River system through the Las Vegas Wash earning "water credits" (Gary Grinnell, LVVWD, personal communication). Utilization of treated sewage effluent (also known as reuse water) for the purpose of landscape irrigation is a more environmentally acceptable alternative to the current discharge of reuse water into the Las Vegas Wash and the Colorado River system. The use of reuse water in the Las Vegas Valley is expanding in growth areas in the north and southwest parts of the valley (satellite treatment plants), reducing the need to expand both the water delivery and sewage discharge
Field site and monitoring program design. A monitoring program over a 4.5year period was conducted in the Las Vegas valley to evaluate the impact of golf courses transitioning to reuse water for irrigation purposes. Nine golf courses were selected throughout the valley based on the willingness of golf course superintendents to participate in the monitoring program. Three sites were selected based on long-term (greater than 20 years) irrigation with reuse water, three courses were selected based on transition to reuse water within the monitoring program, and three courses were selected based on no anticipated switch to reuse water within the study period. The monitoring program was originally proposed as a 3-year study; however, as a result of the ongoing drought, the Southern Nevada Water Authority mandated that any golf course located close enough to a wastewater treatment distribution line must switch to reuse water as soon as possible. This altered the monitoring program such that five courses 
switched to reuse water requiring an additional year of field data collection.

Irrigation water for transition courses all originated from satellite treatment plants. Because of the high demand for reuse water, satellite plants were unable to keep up with the demand during peak summer months. Therefore, transition courses received a blend of reuse water and fresh water during the summer. This resulted in water with a lower salinity level (Table $1 ; 1.45 \pm 0.04 \mathrm{dS} \cdot \mathrm{m}^{-1}$ ). Reuse courses received only reuse water directly from the main treatment plants (not satellites) accounting for the three reuse courses having the highest salinity levels $\left(2.10 \pm 0.11 \mathrm{dS} \cdot \mathrm{m}^{-1}\right)$.

Monthly questionnaires were sent to all participating superintendents requesting information on irrigation amounts and times, fertilizer types and amounts, and fairway/ green mowing heights.

Soil classification for each golf course fairway and turfgrass species growing on fairways and greens are listed in Table 1. All courses with the exception of transition course $(T)$ were overseeded with perennial ryegrass in September of each year.

Each monitoring site on the fairway and greens was instrumented with salinity and soil moisture sensors at depths of $15,45,75$, and $105 \mathrm{~cm}$. Salinity sensor data were collected bimonthly using a salinity bridge (Model 5500; Soil Moisture Corporation, Santa Barbara, CA). Soil volumetric water content data were also collected bimonthly with a Trace System I (Soil Moisture Corpo- ration). Surface soil moisture content (0 to 6 $\mathrm{cm}$ ) was assessed using a theta probe (Type ML2x; Delta T Devices, Cambridge, U.K.).

Water meters were placed on all laterals that delivered water to the monitoring locations on all nine golf course fairways. Bimonthly water meter readings were taken at each site to monitor irrigation volumes. Precipitation curves (pressure-volume-time) were established using collection cups placed in a grid pattern for all irrigation cells containing sensors. Actual precipitation associated with each irrigation event was predicted by using the established curves corresponding to each site. Water balances were maintained by monitoring irrigation input and estimating water loss through evapotranspiration by adjusting potential evapotranspiration estimates with appropriate crop coefficients (Devitt et al., 1992, 2007). Leaching fractions (LF, drainage volume/ irrigation volume) were assessed using the following equation:

$$
\mathrm{LF}=\frac{\mathrm{I}-\left(\mathrm{ET}_{\mathrm{o}} \cdot \mathrm{Kc}\right)}{\mathrm{I}}
$$

where $\mathrm{I}$ is irrigation volume, $\mathrm{ET}_{\mathrm{o}}$ is the Penman Monteith potential ET estimate, and $\mathrm{K}_{\mathrm{c}}$ is the crop coefficient.

The physiological status of the turfgrass on the fairways and greens was assessed monthly. All measurements were taken in triplicate and acquired between 1130 and 1400 HR. At the canopy level, chlorophyll was estimated using a portable chlorophyll meter (Model CM 1000; Spectrum Technol- ogies, Inc., Plainfield, IL). Leaf xylem water potential $\left(\psi_{\mathrm{L})}\right.$ was assessed using a Scholander Pressure Chamber (Model 3005; Soil Moisture Corporation). Great care was required to accurately estimate $\psi_{\mathrm{L}}$ on ryegrass, often requiring five to eight samples before three measurements were deemed acceptable. The successful technique always required new sealing grommets, a slow application of pressure, and a lower cut on the stem. Tissue moisture was obtained from plant tissue harvested monthly from each site and collected in preweighed and labeled collection cups. The cups were taken back to the laboratory and quickly weighed to estimate the initial total fresh weight. Samples were then oven-dried at $70{ }^{\circ} \mathrm{C}$ for a period of $48 \mathrm{~h}$ and tissue moisture content was calculated based on the fresh and oven-dried weights.

Color of the turfgrass was evaluated with a rating system that ranged from 0 to 10 with 0 the number assigned to dead turfgrass and 10 representing turfgrass with a deep green color. The cover rating ranged from $0 \%$ to $100 \%$ in which $0 \%$ represented bare soil and a rating of $100 \%$ represented full canopy cover. Canopy cover data are not reported because no loss in cover was noted.

In the spring of each year of the monitoring program, 25 soil samples $(0$ to $15 \mathrm{~cm})$ were taken on both fairways and greens in a 5 $\times 5$ grid (based on 2.75-m spacing). These grids enclosed the sensor location at each site. The soil samples were analyzed for gravimetric water content and saturation extract soil salinity (ECe).

Table 1. Site characteristics.

\begin{tabular}{|c|c|c|c|c|}
\hline Golf course & Irrigation status & EC water $\left(\mathrm{dS} \cdot \mathrm{m}^{-1}\right)$ & Turfgrass (fairway/green) ${ }^{z}$ & $\begin{array}{c}\text { Soil classification } \\
\text { (fairways and greens) }^{y}\end{array}$ \\
\hline$\overline{\mathrm{P}}$ & Fresh & 0.80 & $\begin{array}{l}\text { Common bermudagrass/SR1020 creeping } \\
\text { bentgrass }\end{array}$ & $\begin{array}{l}\text { Glen carb very fine sandy loam } \\
\text { (fine-silty, carbonatic, thermic } \\
\text { Typic Torrifluvents) }\end{array}$ \\
\hline B & Reuse & 2.00 & $\begin{array}{l}\text { Common bermudagrass/Penlinks creeping } \\
\text { bentgrass }\end{array}$ & $\begin{array}{l}\text { Arizo very gravelly fine sandy } \\
\text { loam (sandy-skeletal, mixed, } \\
\text { thermic Typic Torriorthents) }\end{array}$ \\
\hline $\mathrm{L}$ & Reuse & 2.07 & $\begin{array}{l}\text { Tifway hybrid bermudagrass/Tifgreen hybrid } \\
\text { bermudagrass }\end{array}$ & $\begin{array}{l}\text { Arizo extremely stony loam } \\
\text { (sandy-skeletal, mixed, thermic } \\
\text { Typic Torriorthents) }\end{array}$ \\
\hline W & Reuse & 2.22 & $\begin{array}{l}\text { Tifway hybrid bermudagrass base } \\
\text { and common bermudagrass/TifEagle hybrid } \\
\text { bermudagrass }\end{array}$ & $\begin{array}{l}\text { McCarran fine sandy loam } \\
\text { (coarse-loamy, mixed, thermic } \\
\text { Cambic Gypsiorthids) }\end{array}$ \\
\hline A Day 534 & Transition & $0.98 / 1.51^{\mathrm{x}}$ & $\begin{array}{l}\text { Common bermudagrass base plus annual } \\
\text { bluegrass/Tifgreen hybrid bermudagrass base } \\
\text { plus annual bluegrass (2001), Tifdwarf hybrid } \\
\text { bermudagrass (2002-2004) }\end{array}$ & $\begin{array}{l}\text { Cave gravelly fine sandy loam } \\
\text { (loamy, mixed, thermic, } \\
\text { shallow Typic Paleorthids) }\end{array}$ \\
\hline C Day 1309 & Transition & $0.95 / 1.40$ & $\begin{array}{l}\text { Tifway hybrid bermudagrass/Pencross } \\
\text { creeping bentgrass }\end{array}$ & $\begin{array}{l}\text { Cave gravelly fine sandy loam } \\
\text { (loamy, mixed, thermic, } \\
\text { shallow Typic Paleorthids) }\end{array}$ \\
\hline R Day 1353 & Transition & $0.99 / 1.40$ & $\begin{array}{l}\text { Blend of } 50 \% \text { Palmer perennial ryegrass, } 50 \% \\
\text { Prelude perennial ryegrass }(2001) ; \text { NuMex } \\
\text { Sahara common bermudagrass } \\
(2002-2004) / \text { SR } 1020 \text { creeping bentgrass }\end{array}$ & $\begin{array}{l}\text { Cave gravelly fine sandy } \\
\text { loam (loamy, mixed, thermic, } \\
\text { shallow Typic Paleorthids) }\end{array}$ \\
\hline S Day 1100 & Transition & $0.95 / 1.46$ & $\begin{array}{c}\text { Tifway hybrid bermudagrass } / 33 \% \text { Providence } \\
\text { creeping bentgrass } 33 \% \text { SR } 1020 \text { creeping } \\
\text { bentgrass } 34 \% \text { SR } 1119 \text { creeping bentgrass }\end{array}$ & $\begin{array}{l}\text { Cave gravelly fine sandy loam } \\
\text { (loamy, mixed, thermic, } \\
\text { shallow Typic Paleorthids) }\end{array}$ \\
\hline T Day 695 & Transition & $0.89 / 1.42$ & $\begin{array}{l}\text { Tifway hybrid bermudagrass/Penlinks } \\
\text { creeping bentgrass }\end{array}$ & $\begin{array}{l}\text { Cave gravelly fine sandy loam } \\
\text { (loamy, mixed, thermic, } \\
\text { shallow Typic Paleorthids) }\end{array}$ \\
\hline
\end{tabular}

${ }^{\mathrm{z}}$ Common bermudagrass [Cynodon dactylon (L.) Pers.]; Hybrid bermudagrass [Cynodon dactylon (L.) Pers. $\times$ Cynodon transvaalensis Burtt-Davy]; creeping bentgrass (Agrostis palustris Huds.); perennial ryegrass (Lolium perenne L.); annual bluegrass (Poa annua L.).

${ }^{y}$ All greens were designed and constructed meeting USGA standards (www.usga.org).

${ }^{\mathrm{x}}$ Electrical conductivity (EC) of fresh water/EC of reuse water. 
Data were analyzed using descriptive statistics, analysis of variance, and linear and multiple regression analysis. Multiple regressions were performed in a backward stepwise manner, deleting terms that occurred when $P$ values for the $t$ test exceeded 0.05 . To eliminate multicollinearity, variance inflation factors (VIF) were calculated. Any variable that had a VIF greater than 3 was eliminated from the regression and the analysis was rerun. VIF totals for all variables were not allowed to exceed 10 .

\section{Results}

Soil salinity. Soil salinity $\left(\mathrm{dS} \cdot \mathrm{m}^{-1}\right)$ as a function of depth $(15,45,75,105 \mathrm{~cm})$ was measured with sensors on fairways and greens. Soil salinity from representative fairways irrigated with reuse water, fresh water, or transition to reuse water over the 4.5-year study period are shown in Figure 1. Salinity values varied in a sinusoidal fashion with peak highs and lows that followed the yearly seasonal changes. Summer months were associated with the highest salinity measurements, whereas winter months had the lowest salinity measurements. The greatest oscillation in soil salinity occurred at the shallowest depth of $15 \mathrm{~cm}$. Many courses such as reuse course W (Fig. 1) revealed a well-defined time lag in peak salinity at the deeper depths compared with the $15-\mathrm{cm}$ depth. Reuse courses had peak salinity values in the range of 15 to $40 \mathrm{dS} \cdot \mathrm{m}^{-1}$, which was significantly higher than all transition and fresh courses with the exception of transition courses $R$ and A. In the case of transition course $\mathrm{R}$, the course opened the year before the study was initiated with sod placed on crushed rock and caliche. Transition course A switched to reuse water during the second year of the study with peak summer salinity values as high as $25 \mathrm{dS} \cdot \mathrm{m}^{-1}$ at the 15 -cm depth (Fig. 1).
However, by the third year, salinity values declined. The average fairway soil salinities at all depths before and after transition to reuse water are reported in Table 2 separated based on the time period in which bermudagrass or ryegrass was the dominant species. Only golf course $T$ revealed a statistically significant increase in soil salinity on the fairway at all depths after transition for both the bermudagrass and ryegrass periods. However, it should be noted that transition course $T$ was the only course to not overseed with ryegrass.

Soil salinity in the greens is plotted with depth in Figure 1 for the same three representative courses reported for the fairways. Although salinity in the greens also peaked during summer months, values rarely exceeded $15 \mathrm{dS} \cdot \mathrm{m}^{-1}$ with the exception of transition course $\mathrm{S}$, which had extreme compaction problems and was replaced after the experiment based on these results (data not shown). Sinusoidal oscillations in the soil

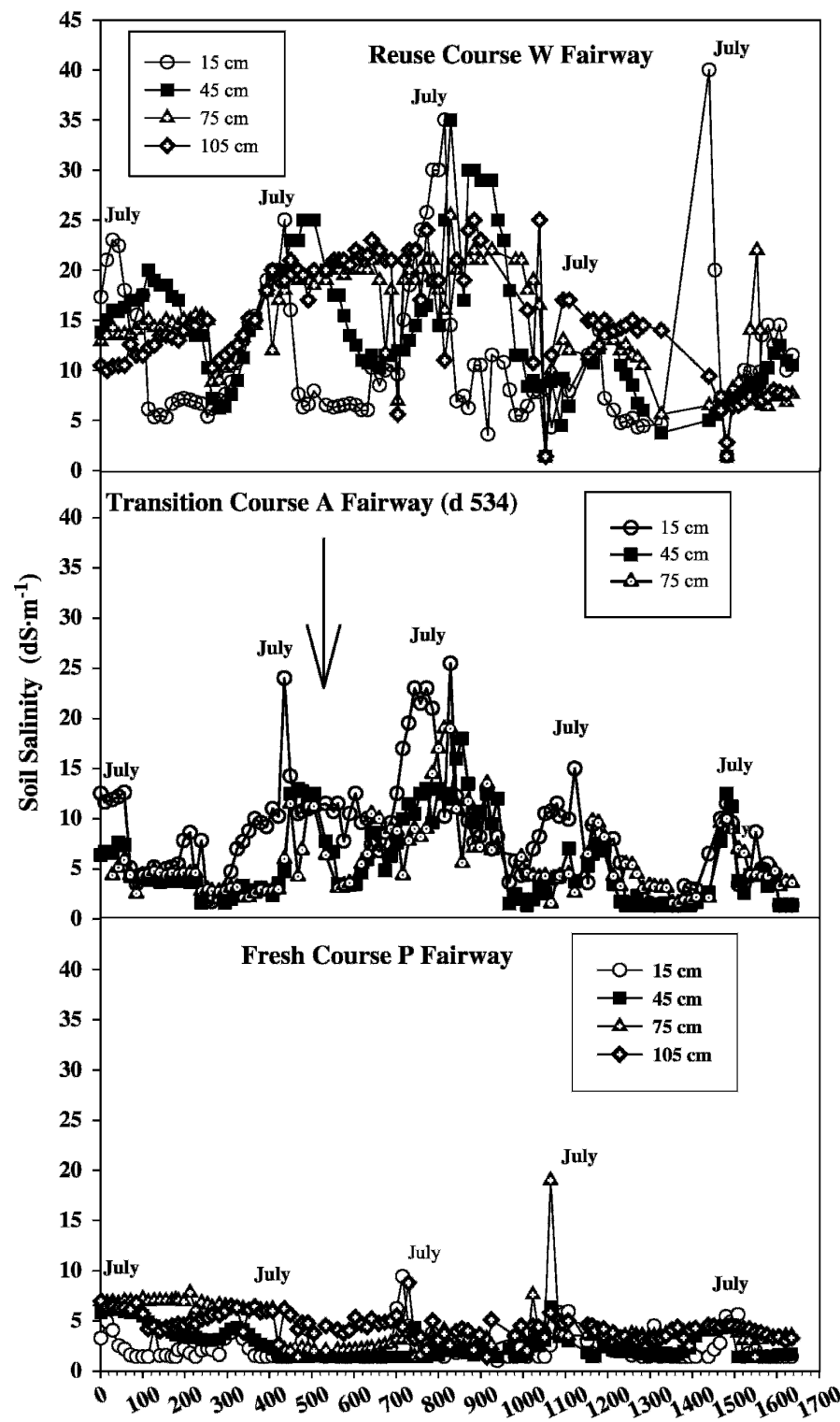

Day of Experiment

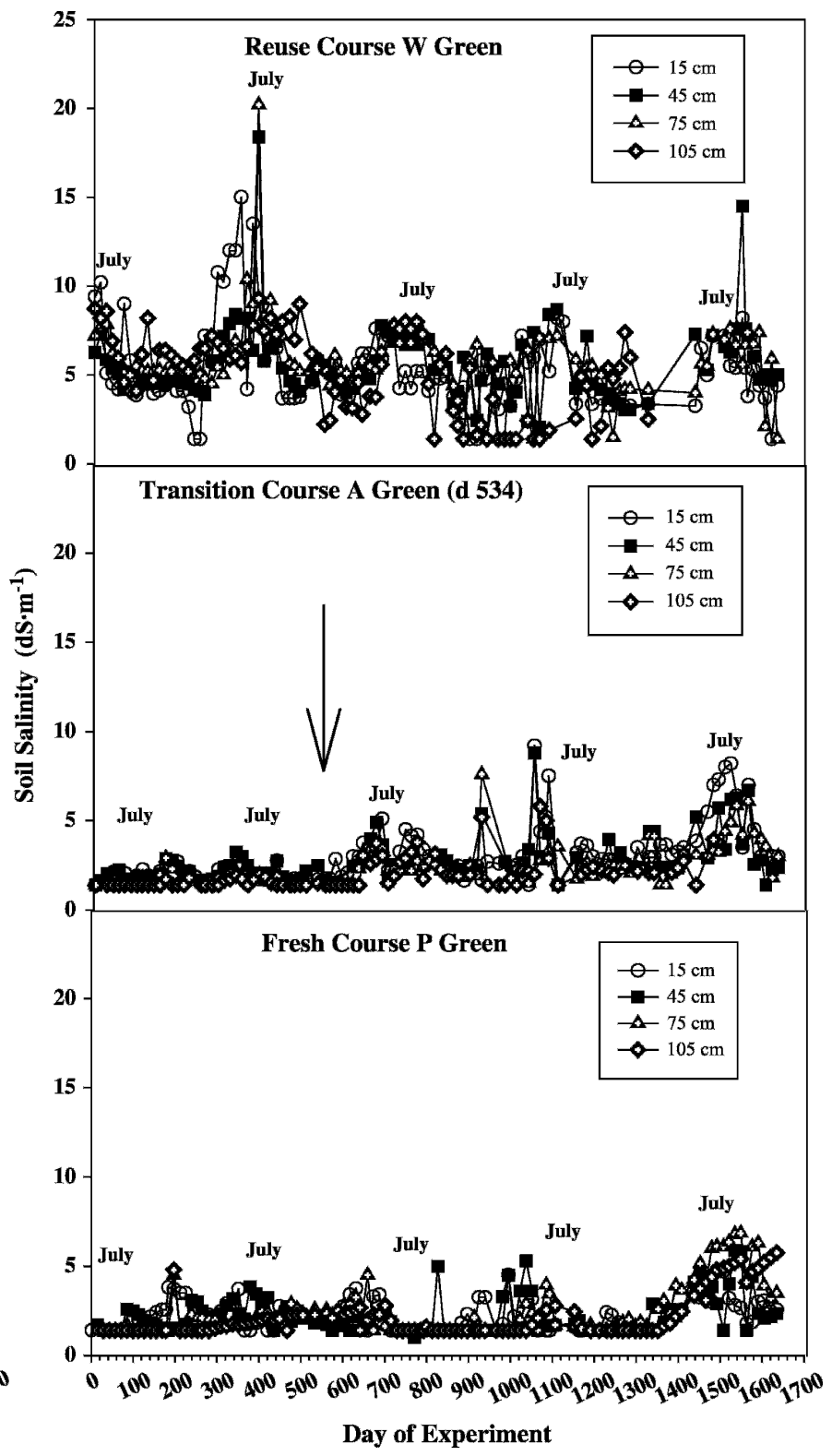

Fig. 1. Soil salinity at the 15-, 45-, 75-, and 105-cm depths on selected fairways and greens irrigated with either reuse water, transition to reuse water, or fresh water over a 4.5 -year period. Day of transition is denoted by arrows. 


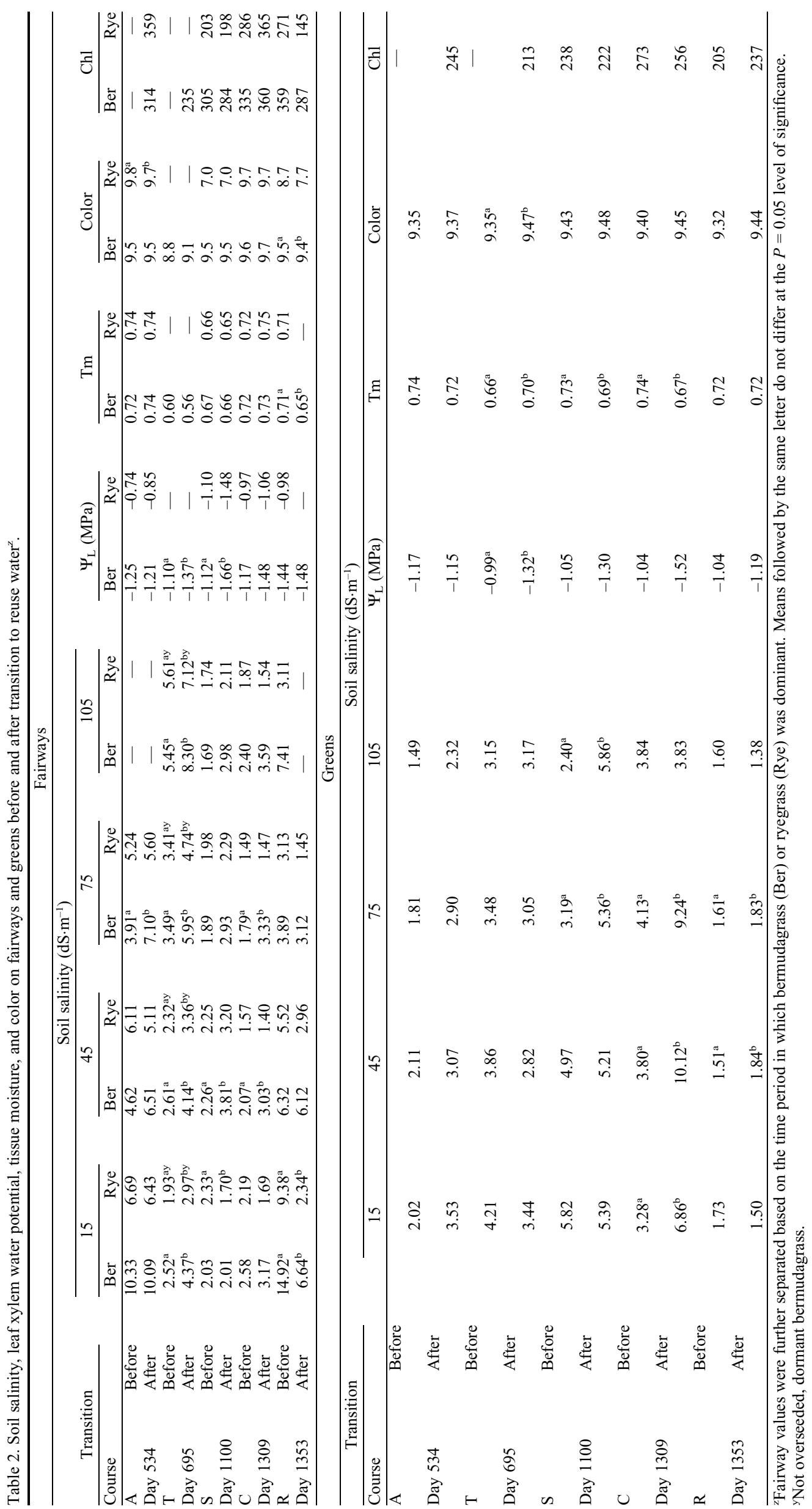



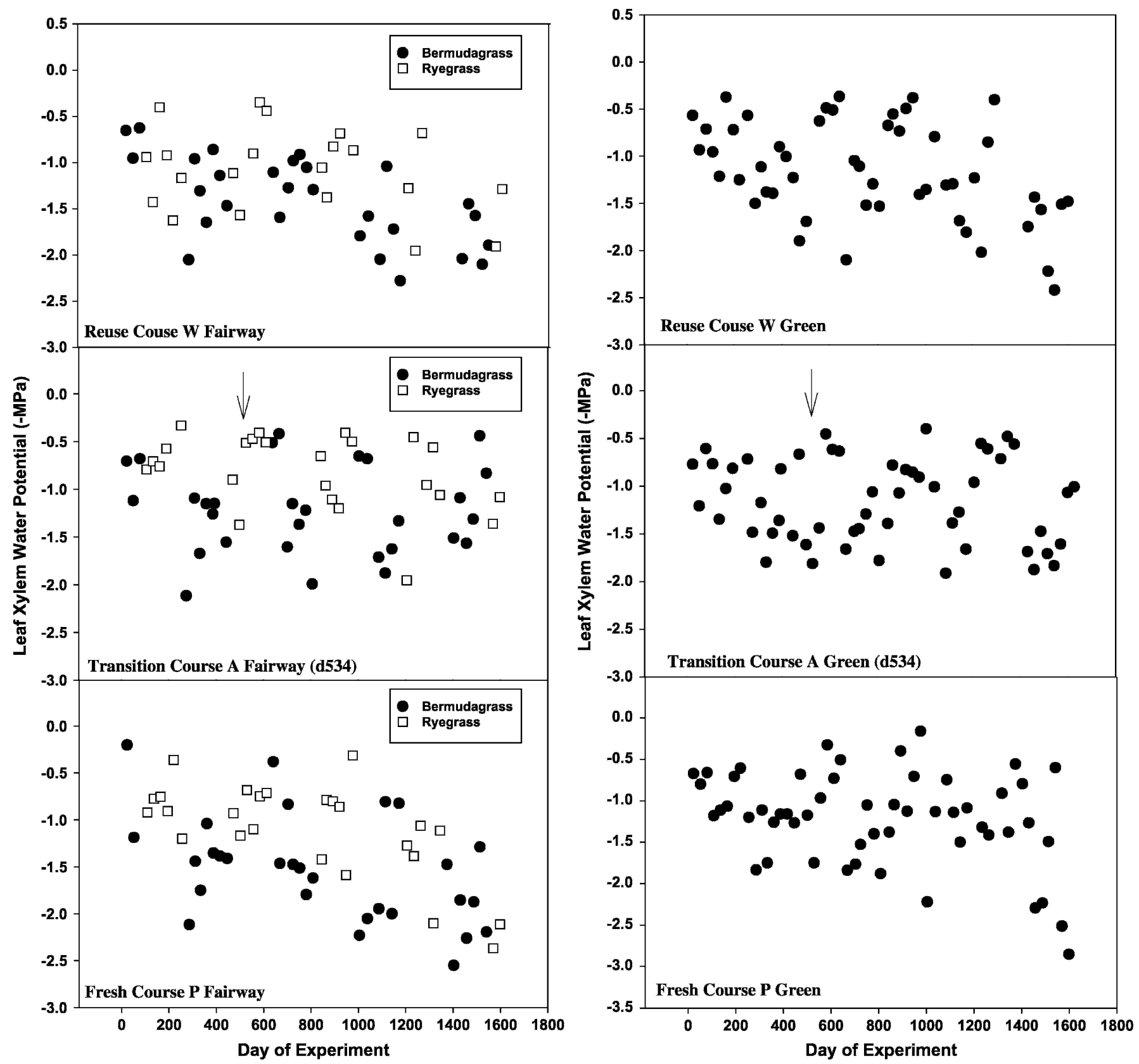

Fig. 2. Leaf xylem water potential (MPa) measured at midday on selected fairways and greens irrigated with either reuse water, transition to reuse water, or fresh water over a 4.5 -year period. Fairway periods dominated by bermudagrass versus ryegrass are given different symbols. Day of transition is denoted by arrows.

salinity of the greens were not as well defined compared with the fairways with little separation in soil salinity with depth. Only in the case of transition course $\mathrm{C}$ was there a clear response to the switch to reuse water. Soil salinity rose from a steady baseline value of $\approx 5 \mathrm{dS} \cdot \mathrm{m}^{-1}$ to over $15 \mathrm{dS} \cdot \mathrm{m}^{-1}$ over a 200 $\mathrm{d}$ period after transition. Average soil salinity at all depths on greens before and after transition to reuse water are also reported in Table 2. The green on golf course A, which had the longest period after transition, revealed no statistical separation in salinity before and after transition. However, course $\mathrm{C}$, which transitioned $775 \mathrm{~d}$ later than course A, showed statistical increases in salinity after transition at the $15-, 45-$, and $75-\mathrm{cm}$ depths and in fact had the highest average soil

Table 3. Irrigation volume and field-based leaching fraction (LF) on a yearly basis.

\begin{tabular}{ccccccccccr}
\hline & & \multicolumn{7}{c}{ Course } \\
\cline { 3 - 11 } & Year & $\mathrm{A}_{\mathrm{T}}{ }^{2}$ & $\mathrm{~B}_{\mathrm{R}}$ & $\mathrm{C}_{\mathrm{T}}$ & $\mathrm{L}_{\mathrm{R}}$ & $\mathrm{P}_{\mathrm{F}}$ & $\mathrm{R}_{\mathrm{T}}$ & $\mathrm{S}_{\mathrm{T}}$ & $\mathrm{T}_{\mathrm{T}}$ & $\mathrm{W}_{\mathrm{R}}$ \\
\hline Irrigation & 2001 & 132.0 & 156.4 & 166.5 & 182.8 & 121.0 & 222.5 & 136.0 & 113.7 & 111.4 \\
$(\mathrm{~cm})$ & 2002 & 123.8 & 201.1 & 211.0 & 238.1 & 141.0 & 278.4 & 174.0 & 145.8 & 134.2 \\
& 2003 & 119.2 & 189.6 & 169.8 & 213.0 & 138.8 & 304.4 & 135.0 & 191.2 & 120.0 \\
& 2004 & 95.8 & 153.0 & 138.3 & 204.2 & 108.8 & 232.5 & 108.8 & 142.4 & 153.3 \\
$\mathrm{LF}$ & 2001 & 0.05 & 0.20 & 0.25 & 0.31 & -0.04 & 0.37 & 0.08 & -0.11 & -0.13 \\
& 2002 & -0.26 & 0.20 & 0.26 & 0.34 & -0.12 & 0.36 & 0.09 & -0.10 & -1.80 \\
& 2003 & -0.27 & 0.21 & 0.11 & 0.29 & -0.09 & 0.45 & -0.11 & 0.21 & -0.26 \\
& 2004 & -0.33 & 0.16 & 0.08 & 0.38 & -0.17 & 0.40 & -0.12 & 0.11 & 0.20 \\
\hline
\end{tabular}

${ }^{\mathrm{z} I r r i g a t i o n}$ treatment.

$\mathrm{T}=$ transition; $\mathrm{R}=$ reuse; $\mathrm{F}=$ fresh.

salinity values at those depths for all transition courses.

Plant response. Leaf xylem water potential $\left(\Psi_{\mathrm{L}}\right)$ was monitored monthly at midday on fairways and greens of all courses during the 4.5-year study period. Leaf xylem water potential values on fairways varied with seasonal changes with summer values 
(bermudagrass, June, July, August) decreasing as shown in Figure 2. Leaf xylem water potentials on fairways were measured on bermudagrass during the late spring through early fall period (with the exception of course $\mathrm{R}$, which had ryegrass fairways during the first year) and on perennial ryegrass during the late fall through midspring period. Values for $\Psi_{\mathrm{L}}$ on fairways of both transitional and reuse courses ranged from -0.1 to $-3.8 \mathrm{MPa}$, although values rarely declined below $-2.5 \mathrm{MPa}$. Lowest summer values on reuse courses ranged from -2.4 to 2.5 $\mathrm{MPa}$, whereas transitional course values ranged from -2.1 to $-2.8 \mathrm{MPa}$ (data not shown). Lowest values were not measured on the reuse courses, but instead on transitional courses (T and S) and the fresh course (P).

Plant response on fairways before and after transition are reported in Table 2 . Statistically lower values of $\Psi_{\mathrm{L}}$ for bermudagrass after transition occurred on courses $\mathrm{S}$ and $\mathrm{T}$. However, no statistical separation in $\Psi_{\mathrm{L}}$ occurred with ryegrass. Only on course R did tissue moisture content and color of bermudagrass reveal a statistically lower value after transition and only in the case of ryegrass on transition course A did color decline after transition. No statistical separation in the chlorophyll index occurred on any of the transition courses.

Figure 2 also shows winter and summer oscillations in $\Psi_{\mathrm{L}}$ values on the greens. However, summer $\Psi_{L}$ measured on greens (bermudagrass, bentgrass) rarely declined below $-2.0 \mathrm{MPa}$. Reuse course $\mathrm{W}$ had the lowest summer value at $-2.6 \mathrm{MPa}$. When summer values (June, July, August) were compared between fairways and greens, no statistical separation $(P>0.05)$ occurred. However, midday leaf xylem water potentials measured during summer months for both greens and fairways revealed a significant decreasing relationship over the five summer periods regardless of water quality $\left[\psi_{\mathrm{L}}=-\right.$ 0.92 to 0.0005 (day of experiment; DOE), $R^{2}$ $=0.38^{* * *}$ transition greens, $\psi_{\mathrm{L}}=-0.87$ to 0.0005 (DOE), $R^{2}=0.43^{* * *}$ reuse greens, $\psi_{\mathrm{L}}=-0.99$ to 0.0004 (DOE) $R^{2}=0.31 * * *$ transition fairways, $\psi_{\mathrm{L}}=-0.98$ to 0.0005 (DOE), $R^{2}=0.37 * * *$ reuse fairways]. It is worth noting that the irrigation volume during the last year was the lowest of all years in five of the nine courses and was the lowest of the last 3 years in eight of the nine courses (Table 3), coinciding with the lower $\Psi_{\mathrm{L}}$ values.

Plant response on greens before and after transition are also reported in Table 2. Only on course $\mathrm{T}$ was there a statistically significant decline in $\Psi_{\mathrm{L}}$ after transition. However, both average tissue moisture content and color for the green on course $\mathrm{T}$ revealed a statistical increase in values after transition. The only other significant plant response observed on greens transitioning to reuse water was noted for tissue moisture content on courses $\mathrm{C}$ and $\mathrm{S}$, both revealing a statistical decline in values after transition.

Because maximum stress occurred during summer months, only summer time values (June, July, August) of the plant parameters were plotted as a function of soil salinity at the 15-cm depth in Figure 3 for the fairways. Soil salinity at the $15-\mathrm{cm}$ depth was selected over the depth-averaged soil salinity because of regression analysis results (discussed in the next section). Transition courses (with the exception of course $\mathrm{R}$, which possessed high native salts) revealed a much narrower range in soil salinity than was observed on reuse courses; however, plant response (tissue moisture, $\Psi_{\mathrm{L}}$, color) was either nondistin- guishable from the reuse courses or in fact had the lower response values. Values for each course were contained within an ellipse, minimized in size to contain the maximum vertical and horizontal spread of the data. The shape of the ellipse reflected the different growing conditions and cultural management imposed on each course, indicating that the same plant response could be obtained under a wide range of soil salinity. Although the reuse courses almost always had the higher

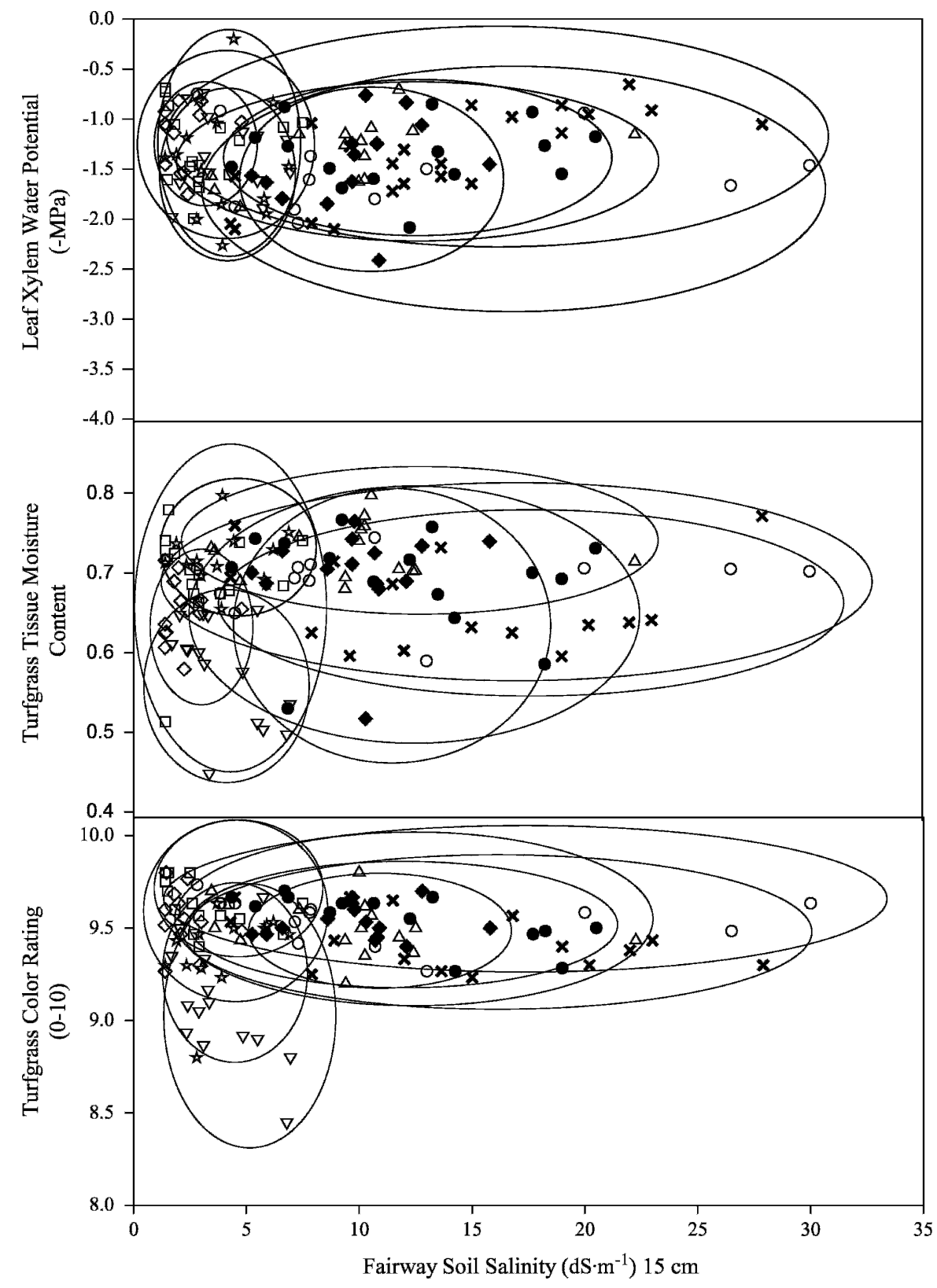

\begin{tabular}{|ll|}
\hline$\Delta$ Course A-transition & $\circ$ Course R-transition \\
- Course B-reuse & $\diamond$ Course S-transition \\
$\square$ Course C-transition & $\nabla$ Course T-transition \\
$*$ Course L-reuse & $\times$ Course W-reuse \\
$\star$ Course P-fresh &
\end{tabular}

Fig. 3. Midday leaf xylem water potential (MPa), tissue moisture content, and color ratings of bermudagrass on fairways during summer months as a function of soil salinity at $15 \mathrm{~cm}$. Values for each course are contained within an ellipse minimized in size to contain the maximum vertical and horizontal spread of the data. 
soil salinity, they did not have the lowest color or tissue moisture content, suggesting that irrigation water quality alone could not explain the response. Chlorophyll index revealed no separation. Transition course $\mathrm{T}$ consistently had the lowest summer values for color and tissue moisture content, yet course $\mathrm{T}$ transitioned after $695 \mathrm{~d}$ and was irrigated with water of $1.42 \mathrm{dS} \cdot \mathrm{m}^{-1}$, significantly lower than $2.0 \mathrm{dS} \cdot \mathrm{m}^{-1}$ water used on the long-term reuse courses. Greater vertical separation in the plant parameter values occurred with the fairways compared with the greens (not shown).

Table 4 reports fairway and green average values for soil salinity at all depths, along with tissue moisture content, color, and chlorophyll index, based on periods of fresh water, transition, or full reuse irrigation. Note that periods before transition were grouped as fresh water. Average soil salinity on the fairways separated statistically at all depths based on irrigation type during the period of active bermudagrass growth with highest average soil salinity on the reuse courses with average values at the 15-, 45-, 75-, and $105-\mathrm{cm}$ depths ranging from 6.59 to 11.28 $\mathrm{dS} \cdot \mathrm{m}^{-1}$. However, a more mixed response was noted during the period of active ryegrass growth, in which soil salinity at most depths in the transition courses could not be distinguished from the fresh water course. Average soil salinity on greens showed no statistical difference between transition and reuse courses.

Plant response revealed a statistical decline in tissue moisture content of bermudagrass on the fairways of transition courses compared with the fresh and reuse courses, but no other statistical separation was observed. In the case of greens, a statistical decline in $\Psi_{\mathrm{L}}$ and chlorophyll index occurred in the transition courses, whereas no statistical separation in color or tissue moisture content was observed. We recognize that turfgrass species often reveal a slight increase in growth, tissue moisture content, and chlorophyll content at moderate levels of salt stress complicating the interpretation (Alshammary et al., 2004; Lee et al., 2004; Marcum and Murdoch, 1990); however, the fact that leaf xylem water potentials and color were not significantly different between fresh and reuse courses but that certain transition courses (Table 2) did reveal significant declines in $\Psi_{\mathrm{L}}$, color, and tissue moisture content indicated that the response was sitespecific and not dependent on irrigation water quality.

Plant response based on soil, plant, and water variables. To assess the impact of sitespecific variables on plant response, we used backward stepwise regression. In particular, color, $\Psi_{\mathrm{L}}$, chlorophyll index, and tissue moisture content were regressed against multiple soil, plant, and water variables [LF, soil water in storage, soil volumetric water content, electrical conductivity (EC) of irrigation water, ECe, EC sensors, tissue moisture, color, chlorophyll index, and $\Psi_{\mathrm{L}}$ ]. When all data were included in the backward regression

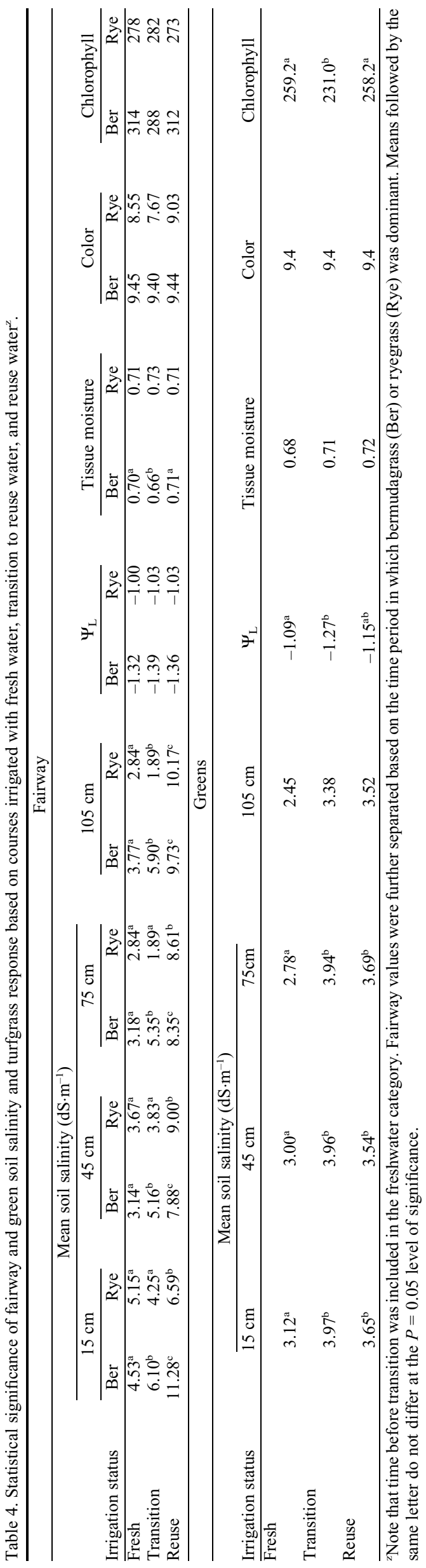

HortScience Vol. 43(7) December 2008 
analysis, no significant correlations existed; however, when the data were analyzed just for summer months (June, July, August), significant correlations existed and are reported in Table 5. However, no significant correlations existed for the greens, no matter how the data were grouped. Highest $R^{2}$ values (Table 5) in the transition courses were for color $\left(R^{2}=\right.$ $\left.0.87^{* * *}\right)$ followed by $\Psi_{\mathrm{L}}\left(R^{2}=0.75^{* * *}\right)$, chlorophyll index $\left(R^{2}=0.65^{* *}\right)$, and tissue moisture content $\left(R^{2}=0.46^{* *}\right)$. Significantly lower $\mathrm{R}^{2}$ values were obtained for these same parameters when data from all courses were included in the regression analysis.

Predictive equations for each plant variable in the transition courses contained either a salinity and/or water parameter. In the case of $\Psi_{\mathrm{L}}$ and tissue moisture content, both a salinity and water parameter were included. These results suggest that any management decisions that alter the water status (LF, soil volumetric water content, soil water in storage) will have a direct impact on plant response (all transition course parameters). However, only in the case of $\Psi_{\mathrm{L}}$ in the transition courses did increasing salinity at the soil surface lead to a decline in $\Psi_{\mathrm{L}}$ values. Based on the results of this study, soil salinity on transition courses as high as 15 to 25 $\mathrm{dS} \cdot \mathrm{m}^{-1}$ on fairways during summer months would not by itself lead to a predictive change in color or the chlorophyll index. This finding was also supported by the results shown in Figure 3 in which higher soil salinity at $15 \mathrm{~cm}$ (or depth averaged salinity, which was rejected in the backward regression analysis) was not correlated with a clear change in the three plant parameters shown. Although LF and the salinity of the irrigation water $\left(E_{i}\right)$ were previously reported to dictate soil salinity (Devitt et al., 2007), the salinity of the irrigation water was rejected in the backward regression analysis for all four plant parameters; however, the outcome of these two factors, soil water content and soil salinity, were shown to be important contributors to plant response.

Table 5. Stepwise multiple regression equations for predicting plant parameters (bermudagrass) based on summer months (June, July, August) in the years 2001 to $2005^{z}$.

\begin{tabular}{|c|c|c|}
\hline Variable & $R^{2}$ & Prediction equation \\
\hline Transition courses & & \\
\hline Color & $0.87 * * *$ & $\mathrm{Y}=8.70+0.002$ (chlor) $+0.15\left(\Psi_{\mathrm{L}}\right)+0.004$ (stor) \\
\hline$\Psi_{\mathrm{L}}$ & $0.75^{* * *}$ & $\mathrm{Y}=-6.68+5.77(\mathrm{TM})+13.34$ (gravi) $+1.69(\mathrm{LF})-0.15\left(\mathrm{EC}_{\mathrm{e} 15}\right)$ \\
\hline Chlorophyll index & $0.65^{* *}$ & $\mathrm{Y}=-129.2+469.9(\mathrm{TM})+1220.0($ gravi $)$ \\
\hline $\begin{array}{l}\text { Tissue moisture } \\
\text { content }\end{array}$ & $0.46^{* *}$ & $\mathrm{Y}=0.45+0.01\left(\mathrm{EC}_{\mathrm{e} 15}\right)+0.59(\theta)$ \\
\hline $\begin{array}{l}\text { All courses } \\
\text { Color }\end{array}$ & $0.57 * * *$ & \\
\hline $\begin{array}{l}\Psi_{L} \\
\text { Chlorophyll index }\end{array}$ & $\begin{array}{l}0.50 * * * \\
0.30 * *\end{array}$ & $\begin{array}{l}\mathrm{Y}=8.87+0.011\left(\mathrm{sal}_{15}\right)+1.60(\theta) \\
\mathrm{Y}=-4.63+2.89(\mathrm{TM})+6.35(\text { gravi })+1.19(\mathrm{LF})\end{array}$ \\
\hline $\begin{array}{l}\text { Tissue moisture } \\
\text { content }\end{array}$ & $0.12 *$ & $\begin{array}{l}\mathrm{Y}=243.4+11.4\left(\mathrm{EC}_{\mathrm{e} 15}\right) \\
\mathrm{Y}=0.76+0.04\left(\Psi_{\mathrm{L}}\right)\end{array}$ \\
\hline
\end{tabular}

${ }^{\mathrm{z} E q u a t i o n s}$ are reported separately for transition courses versus all courses.

$* P<0.05 ; * * P<0.01 ; * * * P<0.001$.

chlor = chlorophyll index; $\Psi_{\mathrm{L}}=$ leaf xylem water potential; stor $=$ soil water in storage $; \mathrm{EC}_{\mathrm{e} 15}=$ saturation extract electrical conductivity at $15-\mathrm{cm}$ depth; $\mathrm{TM}=$ tissue moisture content; gravi $=$ gravimetric water content 0 to $15 \mathrm{~cm} ; \mathrm{LF}=$ leaching fraction; $\theta=$ soil volumetric water content 0 - to $5-\mathrm{cm}$ depth; $\mathrm{sal}_{15}=$ salinity sensor at $15-\mathrm{cm}$ depth; $\mathrm{EC}_{\mathrm{i}}=$ salinity of irrigation water (rejected in all regression analysis). and avoid or minimize plant stress. In a companion paper published by Devitt et al. (2007), yearly changes in depth-averaged salinity sensor values on transitional courses were described by an equation that included the number of days a golf course was irrigated with reuse water, the LF, and the uniformity of the irrigation system $\left(R^{2}=\right.$ $\left.0.83^{* * *}\right)$. Qian and Meecham (2005) stated that appropriate management practices will need to be imposed on a continuous basis to alleviate the negative impact of salt accumulation in the soil associated with using reuse water for irrigation. Wu et al. (1996) reported soil salinity as high as $16 \mathrm{dS} \cdot \mathrm{m}^{-1}$ when irrigating with reuse water; however, they reported that the only salinity effect observed was growth reduction with greater reduction in cool-season grasses compared with warmseason grasses. Mancino and Pepper (1992) reported higher soil salinity under turf irrigated with reuse water compared with potable water with values as high as $12 \mathrm{dS} \cdot \mathrm{m}^{-1}$ in areas with impaired drainage.

Although a significant decline in $\Psi_{\mathrm{L}}$ only occurred on a few courses, the downward trend of summertime leaf xylem water potential associated with courses reducing irrigation volumes is of concern, especially in light of an extended drought in the Colorado River basin. Superintendents will need to be able to assess some form of plant water status (such as tissue moisture content or $\Psi_{\mathrm{L}}$ ), an important component to a multilevel feedback monitoring program. Remote sensing technology may be able to provide this needed feedback. Numerous remote-sensing turfgrass studies have assessed the physiological status of turfgrass and demonstrated the ability of this technique to provide feedback on a relevant time and space basis (Baghzouz et al., 2007; Jiang et al., 1998; Jiang and Carrow, 2005). However, remote sensing will still require field validation such as the monitoring of physiological parameters as reported in this study.

Our results demonstrated that plant response was not being driven by the salinity of the irrigation water or solely by soil salinity and that for plant parameters to change under lower salinity levels indicated that management (irrigation in particular) differed from course to course. The small changes in plant parameters as courses transitioned to reuse water and when transition courses were compared with reuse courses suggests that threshold salinity values were not being exceeded for significant periods of time (Marcum and Pessarakli, 2006). However, our results would also suggest that if irrigation management (LF, irrigation uniformity, irrigation frequency) cannot minimize the intensity and/or duration of salt buildup in the rhizosphere, plant stress can be magnified even when irrigating with water classified as having minimal risk (Ayers and Westcot, 1976). The fact that plant response on reuse courses could not be distinguished from the fresh course may also reflect greater experience in using poor-quality waters by superintendents on long-term reuse courses and the 
need for universities and turfgrass organizations to continually provide educational programming to superintendents to address water management issues. This conclusion is supported by a recent survey published by Devitt et al. (2004) that revealed that among golf course personnel who indicated that using reuse water would have a negative impact on golf course management, a higher percentage were individuals who had a greater number of years of experience irrigating with reuse water $(P=0.01)$ and individuals who had taken classes on how to use reuse water $(P=0.05)$, which led to subsequent changes in irrigation and cultural management practices. However, it was also concluded that golf course personnel did not oppose the transition to reuse water for irrigation.

Finally, it would be extremely valuable to superintendents if water quality data from treatment plants were made available on a daily basis, perhaps in a web-based format, especially on courses that receive blended ratios of reuse water and fresh water that change over time. This would allow the superintendent the ability to implement management options more accurately. Based on the results of this study that monitored soil and plant parameters over a 4.5 -year period, we believe reuse water should be embraced by the golf course industry. Proper irrigation management based on a multitiered feedback system (soil-plant-atmospheric monitoring) should be able to maintain favorable salt balances and plant response as long as irri- gation volumes are not restricted to where deficit irrigation occurs.

\section{Literature Cited}

Alshammary, S.F., Y.L. Qian, and S.J. Wallner. 2004. Growth response of four turfgrass species to salinity. Agr. Water Manage. 66:97-111.

Ayers, R.S. and D.W. Westcot. 1976. Water quality for agriculture. FAO Irrigation and Drainage Paper No. 20. Food and Agriculture Organization of the United Nations, Rome, Italy.

Baghzouz, M., D.A. Devitt, and R.L. Morris. 2007. Assessing canopy spectral reflectance of hybrid bermudagrass under various combinations of nitrogen and water treatments. Applied Engineering in Agriculture 23:1-12.

Borden, B. and R. Fletcher. 2003. Economic Contribution of Nevada's Green Industry Operations on the State of Nevada, 2002. University of Nevada Technical Report UCED 2003/0413.

Carrow, R.N. and R.R. Duncan. 1998. Salt affected turfgrass sites: Assessment and management. Ann Arbor Press, Chelsea, MI.

Devitt, D.A., M. Lockett, R.L. Morris, and B.M Bird. 2007. Spatial and temporal distribution of salts in surface soils of fairways and greens irrigated with reuse water. Agron. J. 99:692-700.

Devitt, D.A., R.L. Morris, M. Baghzouz, and M. Lockett. 2005. Water quality changes in golf course irrigations ponds transitioning to reuse water. HortScience 40:2151-2156.

Devitt, D.A., R.L. Morris, and D.C. Bowman. 1992. Evapotranspiration, crop coefficients, and leaching fractions of irrigated desert turfgrass systems. Agron. J. 84:717-723.

Devitt, D.A., R.L. Morris, D. Kopec, and M. Henry. 2004. Golf course superintendent's attitudes and perceptions toward using reused water for irrigation in the southwestern United States. HortTechnology 14:1-7.

Jiang, H., J.D. Fry, and S.C. Wiest. 1998. Variability in turfgrass water requirements on a golf course. HortScience 33:689-691.

Jiang, Y. and R.N. Carrow. 2005. Assessment of narrow-band canopy spectral reflectance and turfgrass performance under drought stress. HortScience 40:242-245.

Lee, G., R.N. Carrow, and R.R. Duncan. 2004. Photosynthetic responses to salinity stress of halophytic seashore paspalum ecotypes. Plant Sci. 166:1417-1425.

Mancino, C.F. and L.L. Pepper. 1992. Irrigation of turfgrass with secondary sewage effluent: Soil quality. Agron. J. 84:650-654.

Marcum, K.B. and C.L. Murdoch. 1990. Growth responses, ion relations, and osmotic adaptations of eleven $\mathrm{C}_{4}$ turfgrasses to salinity. Agron. J. 82:892-896.

Marcum, K.B. and M. Pessarakli. 2006. Salinity tolerance and salt gland excretion efficiency of bermudagrass turf cultivars. Crop Sci. 46:2571-2574.

Qian, Y.L. and B. Meecham. 2005. Long-term effects of recycled wastewater irrigation on soil chemical properties on golf course fairways. Agron. J. 97:717-721.

U.S. Census Bureau. 2006. State and county quickfacts. 25 Sept. 2008. <http://quickfacts. census.gov/qfd/states/32000.html $>$.

U.S. Golf Association. 1994. Wastewater reuse for golf course irrigation. Lewis Publishers, New York, NY.

Wu, L., J. Chen, P. Van Mantgem, and M.A. Harivandi. 1996. Regenerant wastewater irrigation and ion uptake of five turfgrass species. J. Plant Nutr. 19:1511-1530. 